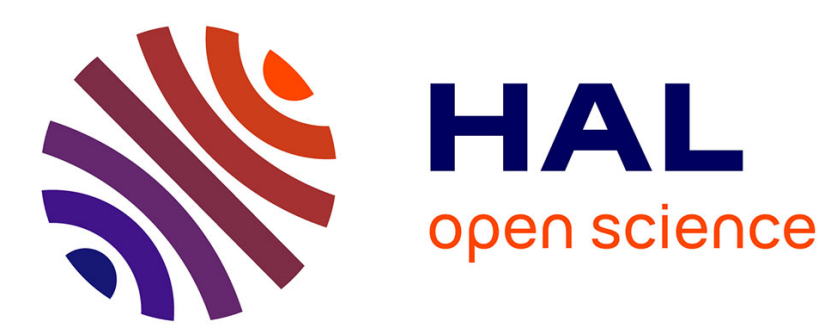

\title{
Influence of moisture content on colour of granular materials. Part I: experiments on yellow ochre
} Amandine Monnard, Dominique Lafon-Pham, Hélène Garay

\section{To cite this version:}

Amandine Monnard, Dominique Lafon-Pham, Hélène Garay. Influence of moisture content on colour of granular materials. Part I: experiments on yellow ochre. Granular Matter, 2016, 18 (3), 10.1007/s10035-016-0650-0 . hal-02078371

\section{HAL Id: hal-02078371 \\ https://hal.science/hal-02078371}

Submitted on 20 Feb 2020

HAL is a multi-disciplinary open access archive for the deposit and dissemination of scientific research documents, whether they are published or not. The documents may come from teaching and research institutions in France or abroad, or from public or private research centers.
L'archive ouverte pluridisciplinaire $\mathbf{H A L}$, est destinée au dépôt et à la diffusion de documents scientifiques de niveau recherche, publiés ou non, émanant des établissements d'enseignement et de recherche français ou étrangers, des laboratoires publics ou privés. 


\title{
Influence of moisture content on colour of granular materials. Part I: experiments on yellow ochre
}

\author{
Amandine Monnard $^{1}$ • Dominique Lafon-Pham ${ }^{1}$ - Helene Garay ${ }^{1}$
}

\begin{abstract}
The water is suspected of remobilizing pigments of prehistoric painting into small worm-like heaps named vermiculations. To preserve these artworks, the moisture con-tent of pigments must be monitored. Due to the fragility of the paintings and the technical constraints on the in-situ measurements, colour measurement is proposed as a noninvasive way to access humidity. This study aims at characterizing more precisely the influence of the moisture content on the optical behaviour of yellow ochre. The light reflected by the surface of drying ochre is measured with a gonio-spectroradiometer. A scenario is proposed: the water saturation at high moisture contents is connected to the presence of a specular radiation which brings a loss of chromatic information. The evaporation of water brings the disappearance of the specular radiation and the augmentation of the diffuse radiation. These first results are promising for the development of a non-destructive in situ method of moisture measurement.
\end{abstract}

Keywords Mineral powder - Colour measurement . Moisture content · Prehistoric parietal art · Vermiculation

\section{Introduction}

Moisture measurements are a key point in many processes: for instance, water can dramatically impact the properties of powders. By binding together hydrophilic particles such as clay or wheat flour, water strongly increases the cohesion of powders $[1,2]$. This well-known ability is at the basis of

Dominique Lafon-Pham

dominique.lafon@mines-ales.fr

1 C2MA - Ecole des mines d'Ales, 6 avenue de Clavières, 30319 Ales Cedex, France wet powder agglomeration, widely used in the foodstuff [1,3] and pharmaceutical industries: the initial moisture content of microcrystalline cellulose influences its tabletability [4]. Relative humidity has to be carefully monitored to have a healthy indoor climate [5,6]. Indeed, it is important to keep relative humidity at $30-60 \%$ to ensure comfortable conditions [6,7]. Humidity can also modify heat transfer properties of granular assemblies [8] High relative humidity can also induce condensation and the growth of micro-organisms [9-11]. Water also damages the structure of buildings by corroding steel, favouring the growth of fungi on wood, and dissolving limestone $[12,13]$. For these reasons, in order to preserve historic heritage, it is important to try to control the presence of water both inside and around artefacts and buildings [13-15]. Regarding the conservation of prehistoric parietal art, water seems to be strongly linked to the occurrence of vermiculations. Discovered in 1906 during a speleological exploration in the Grand Aven de Canjuer (France) [16-18] vermiculations are small worm-like deposits of incoherent materials, such as mud and clay. They are typically observed in cave locations [19-21]. Vermiculations are problematic when they occur on a decorated wall, by remobilizing the pigment of prehistoric paintings [22]. The mechanisms of their formation are not yet well understood, and need to be investigated in order to preserve rock paintings. However many authors suspect water [17,19,23-25], and more precisely, the variation in water content $[26,27]$ to play a leading role in the process. Other studies shows that for some particular moisture contents, the granular assembly is submitted to inter-particle capillary forces [28] and that the rheology of a weakly wetted granular matter depends on the water content [29]. In order better to understand the physico-chemical mecanisms involved in the occurrence of verniculations, and thus preserve prehistoric paintings, variations in the moisture content of the granular deposits have to be characterised. 
Due to the fragility of cave environments, and especially of prehistoric paintings, sampling is strictly forbidden, together with contact, heating and irradiation. These requirements prevent the use of most traditional methods: gravimetric, neutron transmission or scattering, frequency domain reflectometry, microwave sensors [30-34]. Electrical sensors are not suited to highly humid environments such as damp caves. Once the probe is wet, it takes time to dry out and, during this period, it is impossible to monitor humidity changes [5].

A non-destructive method is required. The method has to be contactless and must not cause electromagnetic disturbance. Moreover the presence of water needs to be characterised very near the surface, in the granular structure, regardless of the support. Wet zones must be distinguished from dry zones. In other words, a map of the water distribution needs to be established. Finally, the device has to be portable and to work using batteries as there is no guarantee that an electric plug is available.

We propose the use of colour measurement to monitor variations in the moisture content of granular materials. This method fits all the requirements: no disturbance is created by taking calibrated photos or measuring colour with a spectroradiometer. Moreover, a map of the humidity distribution can easily be drawn from a picture, provided that the presence of water truly affects the colour. Some authors report their observations for hen egg white powder or cottonseed kernel flours that the wetter the powder is, the darker it seems $[35,36]$. But these observations are only for low moisture contents and do not take into account powder saturation phenomena, where liquid water appears between particles [37]. This study is divided in two parts. Part one, presented in this paper focuses on the experiments carried out on very wet samples and their drying at room temperature: the colour changes are measured throughout the process, from high moisture content, up to saturation, until the dry state is reached. Part two, in a second paper details an adaptation of Melamed's Model to simulate the effect of a thin layer of water surrounding the particles, and compares experimental results with simulation results.

\section{Aim and scope}

The aim is to establish a simple way to qualitatively detect the presence of water in a powder through colour measurements. For this reason, the relation between colour and moisture content has to be precisely investigated.

There is a strong relation between moisture content and colour, because of the variation of the scattering of light due to the difference of refractive index between water and air. At high moisture content where a shining effect is observed, the signal is different according to the angle of detection. The sample does not present a Lambertian scattering surface, so the signal cannot be the same in all spatial directions and the total signal cannot be deduced from the measurement at one angle. To study the phenomenon, another device is required which is able to measure radiation reflected in all spatial directions. The commonly-used integrating sphere, is unsuitable as powders can pollute the inside coating of the sphere. That is why a gonio-spectroradiometer is preferable for characterizing the optical behaviour of a drying powder. Once it is characterized, it will be easier to propose an insitu method to monitor the presence of water using portable devices, such as a digital camera or spectroradiometer.

\section{Material and methods}

\subsection{Sample description}

Because of its composition close to that found in cave locations, yellow ochre is the powder investigated here. It comes from the Vaucluse (France), and is commercialized by the society Ôkhra [Conservatoire des ocres et de la couleur, Roussillon (France)] under the nomination "Ocre jaune JFLES no. 27".

The mineralogical species present in the ochre were identified by XRD. Quartz, clay and goethite were found. The dry-phase granulometry was determined using a Beckman Coulter LS13 320 laser diffraction particle size analyser. A bi-modal distribution was found, with $\mathrm{Dm}_{1}=0.8 \mu \mathrm{m}$ and $\mathrm{Dm}_{2}=5.1 \mu \mathrm{m}$.

Samples were prepared in small glass dishes by addition of water on the ochre powder until a consistent paste was obtained, which spreads out to give a smooth and shiny surface. Special attention was paid to the covering power of the paste. The thickness of the paste layer must be sufficient to ensure that the signal measured depends neither on the dish nor on the support below.

\subsection{Devices}

Water content was evaluated by weighing samples (Sartorius BP4100 balance) and expressed as a percentage of the dry basis (\% d.b.), using the formula (1):

Water content $(\%$ d.b. $)=\frac{W_{w e t}-W_{d r y}}{W_{d r y}}=\frac{W_{w a t e r}}{W_{d r y}}$

with $\mathrm{W}_{\text {wet }}$, weight of the wetted sample, i.e. powder plus water; $\mathrm{W}_{\mathrm{dry}}$, weight of the dry sample, which is determined at the end of drying after one night in the oven at $70^{\circ} \mathrm{C}$; $\mathrm{W}_{\text {water }}$, weight of water present in the sample.

The spectrophotometric measurements were performed on a spectrogoniophotometer (GON 360/MAS 40Instrument Systems). On this device, it is possible to move separately the source of light and the sensor and therefore 
to choose the angle between the source and the sample, and between the sample and the sensor. It characterized the two types of information that the visual aspect of the surface depends on:

- Information about brightness, through angular measurement in order to distinguish specular from diffuse reflection. Specular reflection is the part of the radiation reflected as at a mirror surface. It happens when light is reflected into a single direction, making the same angle than the incoming light, with respect to the surface normal. On the contrary, diffuse reflection means light is reflected into many directions. Those phenomena are responsible for the glossy (specular radiation) and matt (diffuse radiation) aspect of surfaces.

- Information about colour through the spectral reflectance, which gives the ratio between the re emitted luminance and the incident luminance in the visible range (380-780 $\mathrm{nm})$.

To calculate the total intensity reflected, two integrations were performed: firstly a spectral integration to give the light intensity for one source/sample/sensor geometry, and secondly a spatial integration to give the total signal.

\subsection{Process}

In order to prevent uncertainties, the two dishes were simultaneously filled with the same quantity of the water/ochre mixture, corresponding to $127 \%$ d.b. One was used to characterize the drying process and the other for the spectrophotometric measurements. Thus all the optical measurements were made in exactly the same zone of the surface of the sample. The samples were dried under ambient conditions $\left(22{ }^{\circ} \mathrm{C}, 55 \%\right.$ relative humidity). The process began with the first gonio-spectroradiometric measurement, very soon after sample preparation. Every $10 \mathrm{~min}$, spectrophotometric measurements were taken and the sample simultaneously weighed.

Each spectrogoniophotometric acquisition consisted of a series of angular measurements corresponding to several geometrical configurations of the sample/detector couple: the incident light source forms an angle of $20^{\circ}$ with the normal axis of the investigated surface. The detector collected the reflected light at different angles in the plane orthogonal to the sample that contains the source: the angular increment varied from large $\left(5^{\circ}\right)$ far from the specular domain to small $\left(0.1^{\circ}\right)$ close to the specular angle value of $-20^{\circ}$.

The experiment ended when the weight of the sample remained constant. Then samples were placed in an oven overnight at $70^{\circ} \mathrm{C}$ and afterward placed in a desiccator with a dried silica bed.

\section{Results and discussion}

\subsection{Drying kinetics}

The drying kinetics are presented Fig. 1. Throughout the drying process, moisture decreases linearly over time, until very low contents (around $3 \%$ d.b.) where the slope of the curve changes.

Weight is lost at a constant rate: this is the well-known constant rate period. Mass transfer is ruled by external conditions such as room temperature and humidity. The constant rate period covers almost all the drying. The falling rate period, that is to say when only bound water remains, controlling the internal mass transfer rate, happens only at the very end of the drying.

This yellow ochre is thus nearly a non-hygroscopic powder. Except for moisture contents below $5 \%$ d.b., most of the water is unbound to the ochre particles. In other words, the water coating practically does not interact with the ochre particles.

\subsection{Radiometric intensity}

Figure 2 shows the variations in the angular distribution of the radiometric intensity during the drying process.

For high moisture content, radiometric intensity is spatially heterogeneous. It presents high value around $-20^{\circ}$ : this makes a typical specular peak. When the yellow ochre is very wet (more than $75 \%$ d.b.), its surface shines brightly, and for this reason, reflectance is overestimated. Then, radiometric intensity becomes more and more spatially homogeneous as the drying continues. The specular peak decreases until it disappears when the powder is dry. The surface is matt at the end of the process.

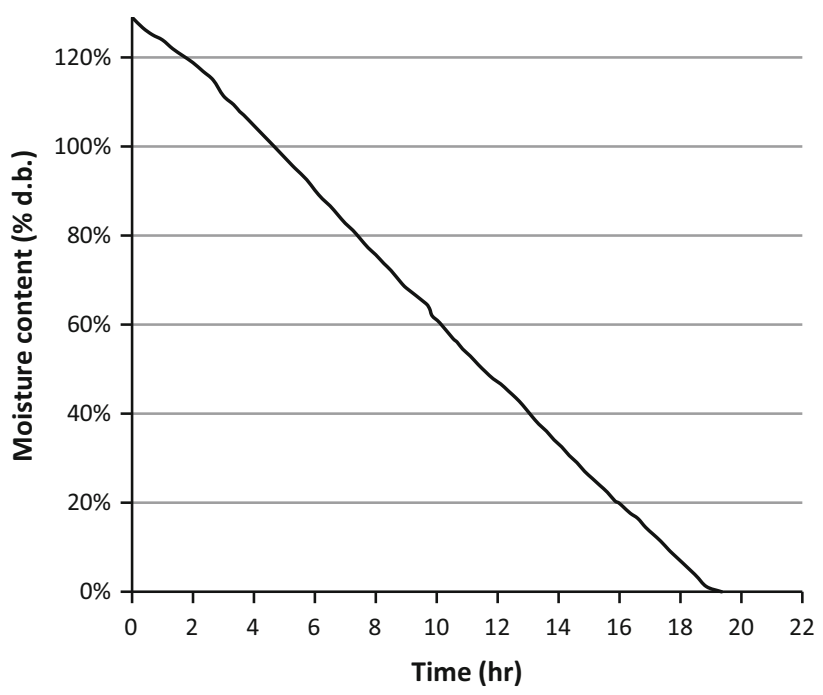

Fig. 1 Drying kinetics of the yellow ochre at room temperature 


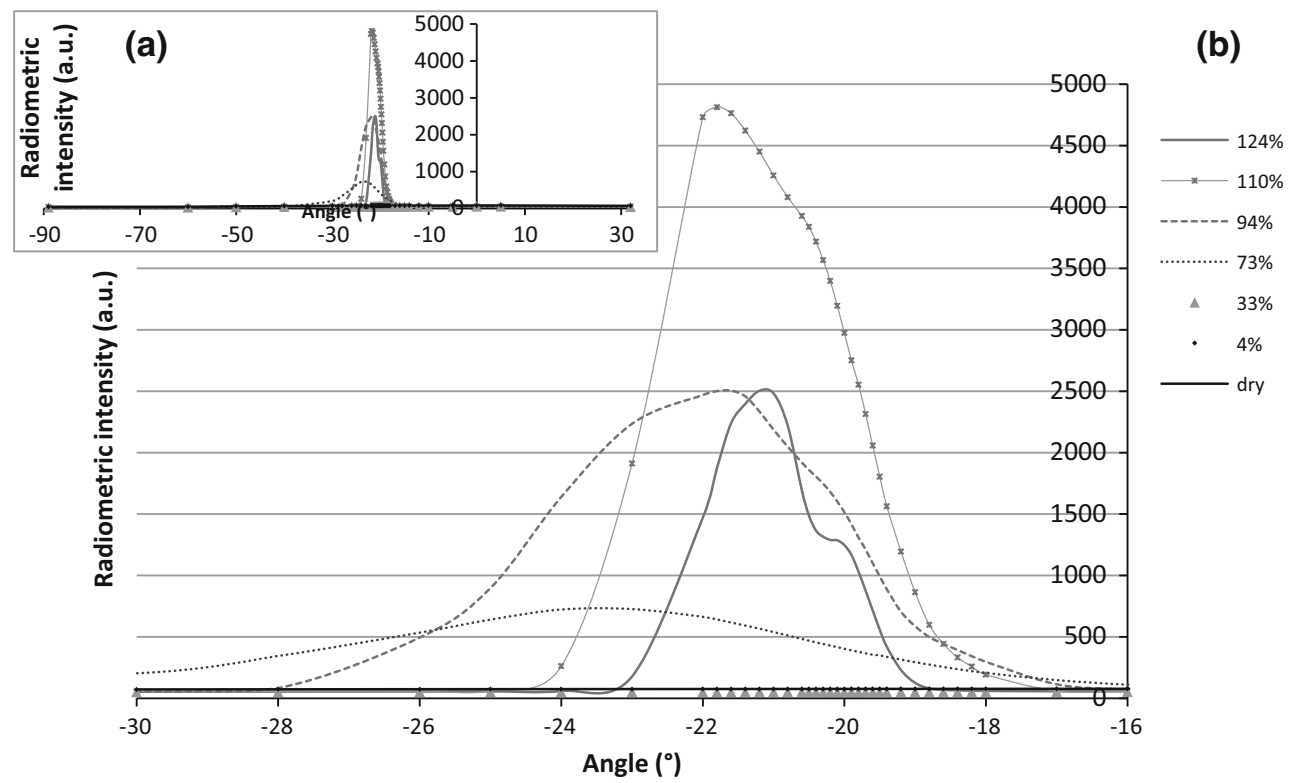

Fig. 2 Evolution in radiometric intensity distribution during the drying process. a Overview of the distribution. A specular peak is clearly observed at $-20^{\circ}$. b Enlargement around the specular domain

Then, the angular contributions are integrated on the half space to obtain the intensity of the total reflected light. It is divided by the signal measured on a white Lambertian scattering material, so it can be express as the percentage of the incident light reflected by the surface: the reflected intensity. Figure 3 represents its evolution against moisture content. At the very beginning of the process, the reflected intensity increases sharply. After passing through a maximum at a moisture content of $110 \%$ d.b., the signal decreases, until it reaches a minimum at $32 \%$ d.b. Then an increase occurs, to reach the final value of the dry state.

Some measured reflectance values seem to be above $100 \%$, which is not physically possible. The surface cannot reflect more energy than it has received. In fact, this is due to measurements performed at close angle range in the specular domain. As the cone of measurement is greater than the solid angle separating positions of measurement in the specular domain, a part of the signal is counted several times. Complementary tests were carried out on a shiny surface in order to verify this hypothesis and indeed, the overestimation of the reflected light grows as the angular increment decreases. This seems to be specific to shiny surfaces. Tests were also done on a matt surface, lacking specular radiation: the same reflected intensity was found, whatever the increment (Fig. 4). For this reason, it seems that measured reflectance overestimates the real reflected light when the specular contribution is high. But if the surface is matt, measured values seem to be close to the actual values.

In order to distinguish between the contributions of specular radiation and diffuse radiation to the total signal measured,

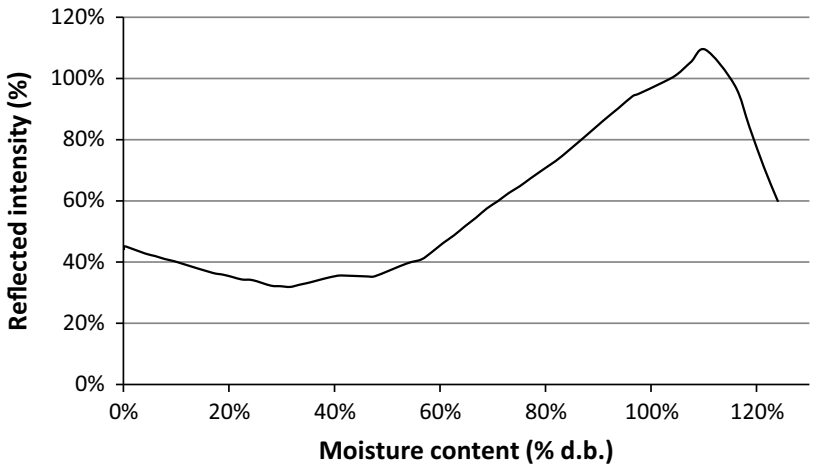

Fig. 3 Evolution of the reflected intensity during drying

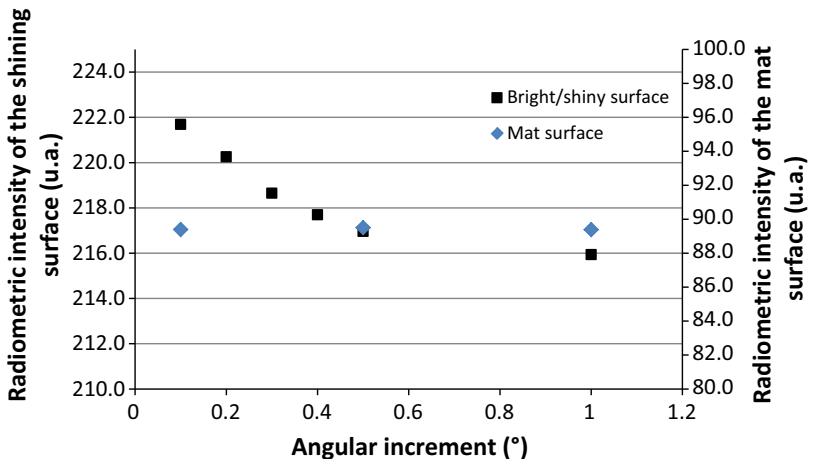

Fig. 4 Effect of angular increment on the diffuse intensity. The smaller the angular increment, the greater the over estimation of the diffuse intensity of a bright surface, while no incidence is found for a mat surface such as the reference white surface 


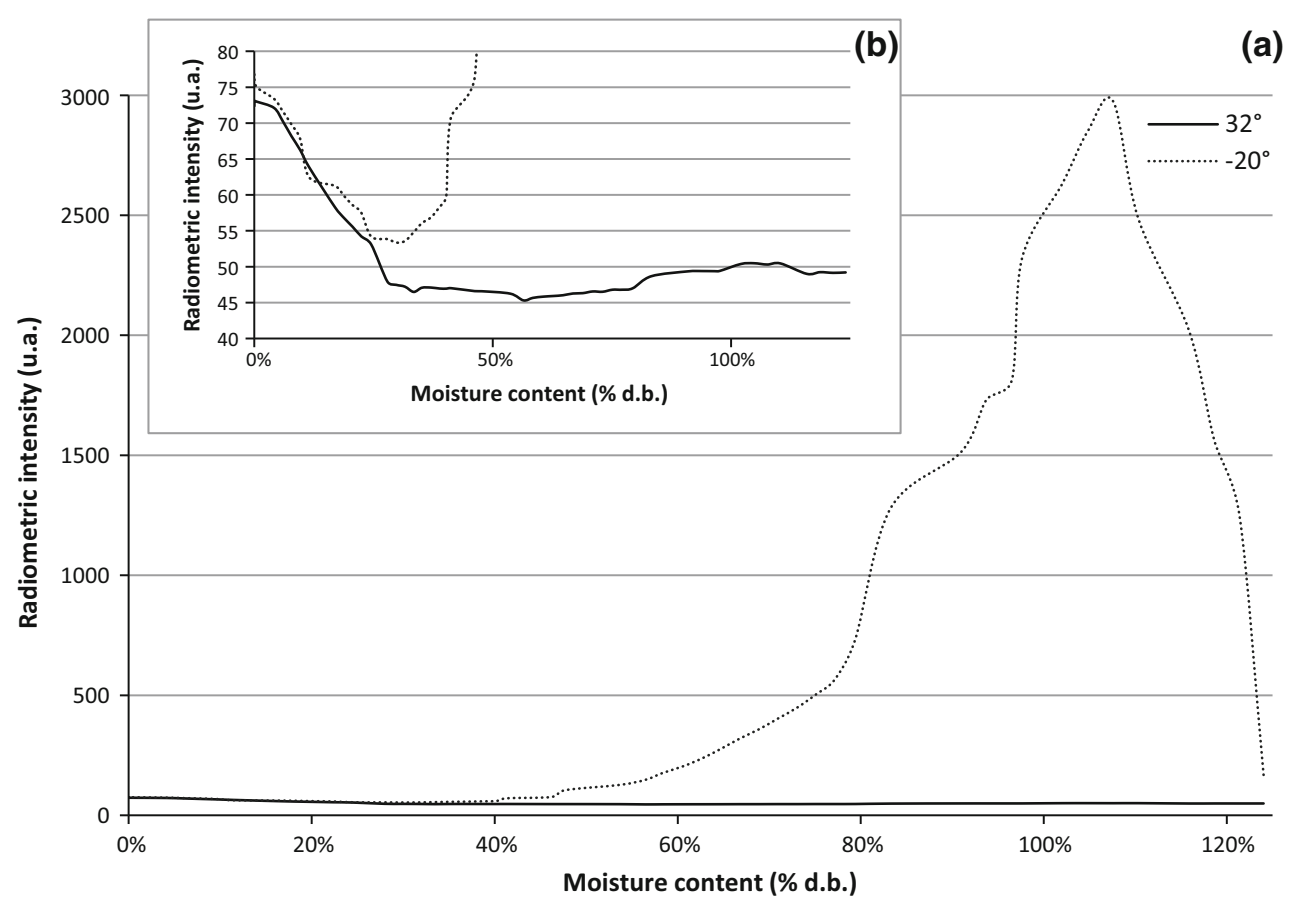

Fig. 5 a Radiometric intensity measured at $-20^{\circ}$ (specular domain) and $32^{\circ}$ (diffuse radiation) b Enlargement for low intensity values

Fig. 5 gives the radiometric intensity measured for two different angles, $-20^{\circ}$ (dotted line) and $32^{\circ}$ (full line).

Like the total reflected intensity, the specular radiometric intensity, measured at $-20^{\circ}$, begins by increasing until reaching a maximum and then decreases sharply to the minimum at $32 \%$ d.b. Finally, a slight increase occurs-this also applies to the total diffuse intensity.

It is different for the radiometric intensity measured at $32^{\circ}$ (diffuse radiation), which does not present the first increase followed by the decrease, but remains almost constant until $30 \%$ d.b. Then, the signal increases to its final value.

If the drying process is watched at $32^{\circ}$, the observer only sees the final increase in the reflected signal. On the contrary, the observer staying at $-20^{\circ}$ sees the same trends as seen for the whole surface, even if the proportions change. The ratio between the minimum measured at $32 \%$ d.b. and the maximum at high moisture content is 3.43 for the whole reflexion, 55.75 at $-20^{\circ}$ and only 1.07 at $32^{\circ}$. In the total reflection, the variations affecting the specular radiation are strongly shaded by the diffuse radiation.

\subsection{Reflectance spectra}

The study of the reflectance spectra gives the influence of the presence of water on the chromatic data. Figure 6 show reflectance spectra respectively measured at $-20^{\circ}$ and $32^{\circ}$ throughout the drying process. The intensity variations have been described above; so this paragraph focuses on the shape of the spectra rather than the level of the signal. First, we have to note that the variations observed for the small wavelengths are due to the electronic noise of the instrument and can't be attributed to physical phenomena.

The $32^{\circ}$ spectra (diffuse radiation) always present two characteristic peaks at 600 and $750 \mathrm{~nm}$, whatever the moisture content (Fig. 6c). However, the presence of water alters the red/blue ratio. The blue and red values are calculated by integration of the signal on respectively $450-500$ and 650 $700 \mathrm{~nm}$. From 8 at high moisture contents, it falls at 4 in the dry state. At high moisture contents, $-20^{\circ}$ spectra (specular domain) are flatter and do not show those peaks (Fig. 6a). However, when the mixture dries, the two peaks progressively appear (Fig. 6b). On the dried ochre, $-20^{\circ}$ and $32^{\circ}$ spectra are closed, as much in intensity as in shape (Fig. 6d). For both, no difference is detectable between spectra measured at the end of the drying process at room temperature, and spectra measured after a night in the oven.

According to the gonio-spectroradiometric measurements, the drying process observed here can be divided in three different steps (Fig. 7).

The first step corresponds to the initialisation of the process. The flattening of the reflectance spectrum from specular domain at high moisture contents means the loss of the chromatic information. This flattening happens progressively at the beginning of the process, at the same time as the increase in the radiometric intensity. Both phenomena are suspected to be due to the sedimentation of the powder when the wetted paste rests in the dish. At the end of this first step, there is a film of water at the surface of the sample 

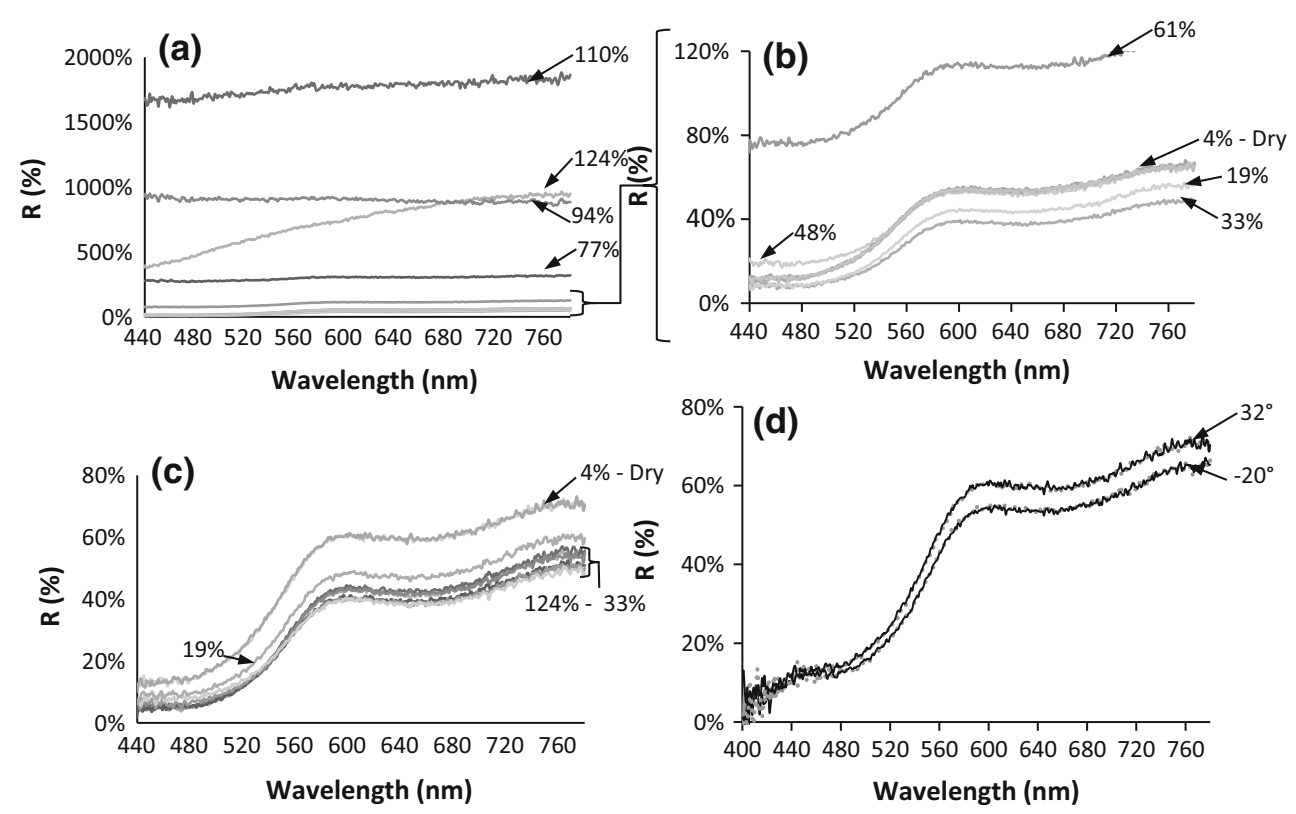

Fig. 6 Evolution of the reflectance spectra of the yellow ochre during the drying process. a Spectra observed at $-20^{\circ}$, in the specular domain. b Enlargement of the $-20^{\circ}$ spectra measured at low moisture content. c

Spectra observed at $32^{\circ}$, in the diffuse domain. $\mathbf{d}$ Comparison between spectra measured at $-20^{\circ}$ and $32^{\circ}$ very low moisture contents: $4 \%$ (do-lines) and dry state (full lines)
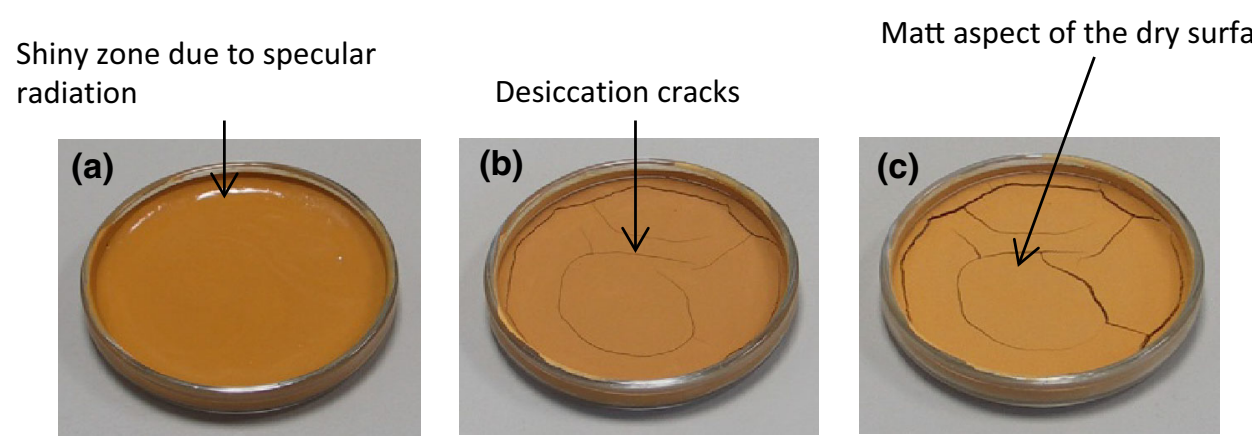

Fig. 7 Photographs of three states of the sample during de drying process. a The sample is very wet and the surface shines. b Specular radiation has disappeared and desiccation cracks have appeared. $\mathbf{c}$ The matt surface brightens at the end of the drying

corresponding to the maximum of specular reflection and the achromatic spectrum (Figs. 7a, 8a).

Then, the water present in the sample progressively evaporates. The film becomes thinner and thinner until it disappears (Fig. 8). Water only remains in the bulk of the mixture, between and around the particles of ochre (Fig. 8c). Once more, water is steadily replaced by air in the granular structure and desiccation cracks appear (Fig. 7b). This second phase corresponds to the decrease in the signal and the apparition of the characteristic peaks on reflectance spectra. As the specular radiation is achromatic, its disappearance means the return of detectable chromatic information (Fig. 6a, b).

The curve shows a minimum before a new increase in the signal. The water coating disappears, until nothing remains around the particles except very few adsorbed molecules of water that have very low incidence on the measurement (Figs. 7c, 8d).

\section{Conclusion}

This study shows how reflectance measurements can provide information about the water content of a powder. Observing the drying process of a yellow ochre, four steps were identified, the first corresponding to the sedimentation of the ochre in the bottom of the dish. The three others depend on the state of the mixture water/particles. Firstly a layer of water at the surface of the sample leads it to shine brightly and increases the specular reflection. Its evaporation causes the decrease in the signal. Then, water remains in the bulk of the 


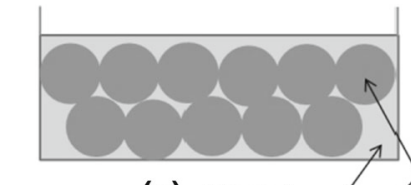

(a) : Stage 1

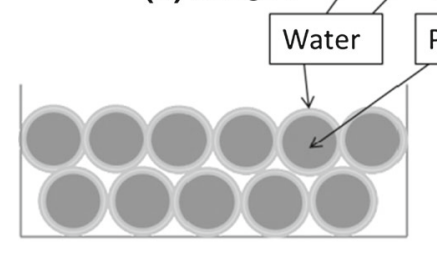

(c) : Stage 3

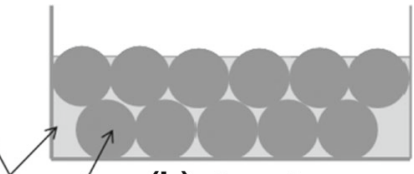

(b) : Stage 2

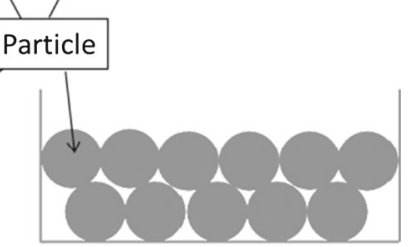

(d) : Stage 4
Fig. 8 A simple schematization of the evolution of the water-powder mixture during drying: a Particles lie at the bottom of the dish while a thin continuous layer of water covers the surface. b As water evaporates, the water film disappears. $\mathbf{c}$ Water only remains around the particles. $\mathbf{d}$ Water has totally disappeared, this is the dry state

sample, around particles, decreasing the scattering efficiency. The evaporation of this film causes the lightening of the sample. These observations are in accordance with the accepted fact that damp samples are darker than the dry ones, as can be observed with sand for example. Finally, only a few particles of water remain: for low moisture content $(<2 \%)$, no variation is detectable.

Using colour as a sensor for moisture content in a granular structure seems to be a promising non-destructive method. With some additional works to adapt the method to the special environmental conditions of measuring in caves, we can hope to have a method to estimate the water content of granular matter on the walls and try to give elements to explain the phenomenon of vermiculations Part 2 of this study will aim at modelling these three steps using the Melamed Model.

\section{References}

1. Iveson, S., Litster, J., Hapgood, K., Ennis, B.: Nucleation, growth and breakage phenomena in agitated wet granulation processes: a review. Powder Technol. 117, 3-39 (2001) (Granulation and Coating of Fine Powders)

2. Isrealachvili, J.: Intermolecular an Surface Forces: Revised Third Edition, 3rd edn. Academic Press, San Diego (2011)

3. Barkouti, A., Delalonde, M., Rondet, E., Ruiz, T.: Structuration of wheat powder by wet agglomeration: case of size association mechanism. Powder Technol. 252, 8-13 (2014)

4. Shi, L., Feng, Y., Sun, C.: Initial moisture content in raw material can profoundly influence high shear wet granulation process. Int. J. Pharm. 416, 43-48 (2011)

5. Alwis, L., Sun, T., Grattan, K.T.V.: Optical fibre-based sensor technology for humidity and moisture measurement: review of recent progress. Measurement 46, 4052-4074 (2013)

6. Kalamees, T., Korpi, M., Vinha, J., Kurnitski, J.: The effects of ventilation systems and building fabric on the stability of indoor temperature and humidity in Finnish detached houses. Build. Environ. 44, 1643-1650 (2009)
7. Green, J., Dyer, I.: Measurement of humidity. Anaesth. Intensive Care Med. 10, 45-47 (2009). Orthopaedics

8. Yun, T.S., Santamarina, J.C.: Fundamental study of thermal conduction in dry soils. Granul. Matter 10, 197-207 (2008)

9. Muynck, W., Cox, K., Belie, N., Verstraete, W.: Bacterial carbonate precipitation as an alternative surface treatment for concrete. Constr. Build. Mater. 22, 875-885 (2008)

10. Viitanen, H.A., Vinha, J.B., Salminen, K.B., Ojanen, T.A., Peuhkuri, R.A., Paajanen, L.A., Lähdesmäki, K.B.: Moisture and bio-deterioration risk of building materials and structures. J. Build. Phys. 33, 201-224 (2010)

11. Johansson, P., Ekstrand-Tobin, A., Svensson, T., Bok, G.: Laboratory study to determine the critical moisture level for mould growth on building materials. Int. Biodeterior. Biodegrad. 73, 23-32 (2012)

12. Kalamees, T., Vihna, J., Kurnitski, J.: Indor humidity loads and moisture production in lightweight timber-frame detached houses. J. Build. Phys. 29, 219-246 (2006)

13. Kisternaya, M., Kozlov, V.: Preservation of historic monuments in the "Kizhi" open-air museum (Russian Federation). J. Cult. Herit. 13, S74-S78 (2012) (Wood Science for Conservation)

14. Martinez-Garrido, M.I.S., Aparicio, R., Anaya, J.J., Izquierdo, M.A.G.: Effect of solar radiation and humidity on the inner core of walls in histoirc buidings. Construct. Build. Mater. 51, 38-394 (2014)

15. Hradil, P., Toratti, T., Vesikari, E., Ferreira, M., Häkkinen, T.: Durability considerations of refurbished external walls. Construct. Build. Mater. 53, 162-172 (2014)

16. Martel, E.A.: Étude sur la source de Fontaine-l'Évêque. Annales d'Hydraulique Agricole 33, 374-381 (1906)

17. Renault, P.: Dépôts vermiculés d'argile. In: Comité national de spéléologie (ed.) 1er Congrès Internationnal de Spéléologie. Museum national d'histoire naturelle, Paris, France (1953)

18. Hill, C.A.: Mud and clay vermiculations. In: Cave Minerals of the world, Huntsville, USA, pp. 221-223 (1997)

19. Jeannel, R., Racovitza, E.G.: Biospeologica-Énumération des grottes visitées (1918-1927). Arch. de zoologie expérimentale et générale 68, 293-608 (1929)

20. Choppy, J.: Vermiculures d'argile sur une coulée stalagmitique. Bull. du Comité Natl. de Spéléologie 5e année 3, 6 (1955)

21. Renault, P.: États de parois en cavernes. Vermiculations argileuses et cristallisations de gypse. Annale de Spéléologie 14, 249-252 (1959)

22. Hoerlé, S., Konik, S., Chalmin, E.: Les vermiculations de la grotte de Lascaux : identitfication de sources de matériaux mobilisables par microanalyses physico-chimiques. Karstologia 58, 29-40 (2011)

23. Pommier, C., Garnier, J.J.: A propos des "Vermiculations argileuses". Bull. du Comité Natl. de Spéléologie 5e année 1, 7-8 (1955)

24. Barr, T.C.: A possible origin for cave vermiculations. Natl. Speleol. Soc. News 15, 34-35 (1957)

25. Renault, P.: Observations récentes sur les vermiculations argileuses. Spélunca 3, 25-28 (1963a)

26. Bini, A., Gori, M., Gori, S.: A critical review of hypothèses on the origin of vermiculations. Int. J. Speleol. 10, 11-33 (1978)

27. Montoriol-Pous, J.: Sobre el origen de las vermiculaciones arcillosas. In: 2ème Congrés International Spéléologie, Bari, vol. 1, pp. 389-395 (1958)

28. Harireche, O., Faramarzi, A., Alani, A.M.: Prediction of interparticle capillary forces for non-prefectly wettable granular assemblies. Granul. Matter 17, 537-543 (2015)

29. Schwarze, R., Gladkyy, A., Uhlig, F., Luding, S.: Rheology ok weakly granular materials: a comparison of experimental and numerical data. Granul. Matter 15, 455-465 (2013)

30. Okamura, S.: Microwave technology for moisture measurement. Subsurf. Sens. Technol. Appl. 1, 205-227 (2000) 
31. Cancilla, P.A., Barette, P., Rosenblum, F.: On-line moisture determination of ore concentrates 'a review of traditional methods and introduction of a novel solution'. Miner. Eng. 16, 151-163 (2003)

32. Robens, E., Rübner, K., Staszczuk, P.: Gravimetric measurement of water vapour sorption, moisture and dry mass. J. Therm. Anal. Calorim. 76, 639-646 (2004)

33. Monti, A., Zatta, A.: Root distribution and soil moisture retrieval in perennial and annual energy crops in Nothen Italy. Agric. Ecosyst. Environ. 132, 252-259 (2009)

34. Abd, A., Abdel-Monem, A.M., Kansouh, W.A.: Experimental determination of moisture distributions in fired clay brick using a $252 \mathrm{Cf}$ source: A neutron transmission study. Appl. Radiat. Isot. 74, 78-85 (2013)
35. Tchiegang, C., Kapseu, C.: Influence de l'humidité, des teneurs en coques et en gossypol total sur la couleur de la farine des amandes de graines de cotonnier. J. Food Eng. 34, 259-270 (1997)

36. Rao, Q., Labuza, T.: Effect of moisture content on selected physicochemical properties of two commercial hen egg white powders. Food Chem. 132, 373-384 (2012)

37. Nadeau, J.-P.: Séchage: des processus physiques aux procédés industriels. Technique et Documentation-Lavoisier, Paris (1995) 